\title{
Effect of Stock Market Development on Economic Growth: Case Study Egypt
}

Marina Adly Wahba, Mohraeil Adel Fayez, Monica Magdy Louise,

Sherry Samir Fawzy, Fatma El Zahraa Galal.

Graduates of Faculty of Economics and Political Science

- Cairo University

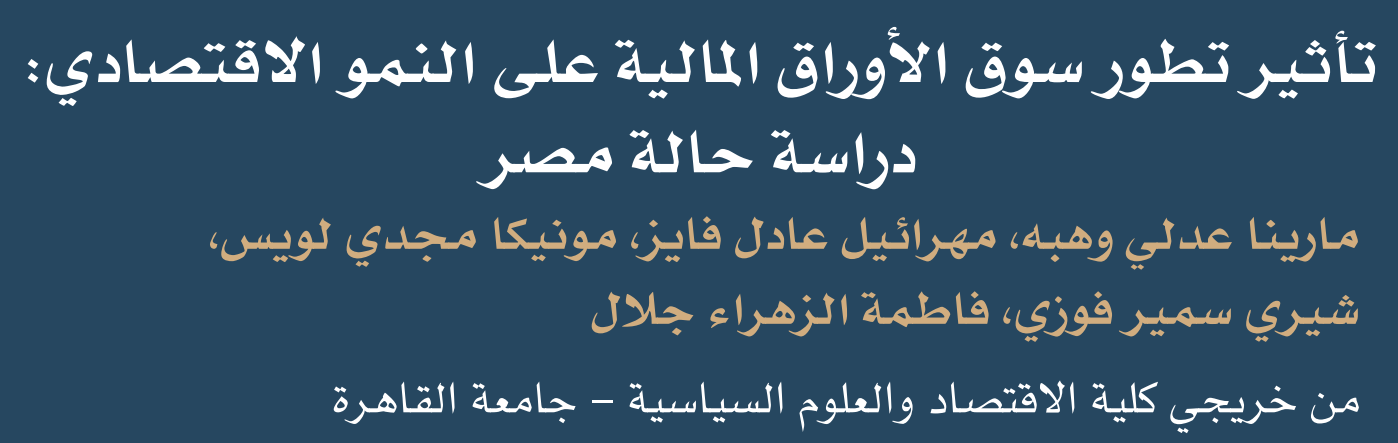

(*) The research was supervised by Dr. Hebatalla Atef Emam, Assistant Professor at Faculty of Economics and Political Sciences, Cairo University.

Hebatalla.atef@feps.edu.eg

Correspondence:

Marina Adly Wahba, Mohraeil Adel Fayez, Monica Magdy Louise, Sherry Samir Fawzy, and Fatma El Zahraa Galal.

Graduates of Faculty of Economics and Political Science- Cairo University

E-mail: Marina.adly2017@feps.edu.eg, mehraial.adel2017@feps.edu.eg,monica.louise2017@ feps.edu.eg, sherry.samir2017@feps.edu.eg, fatma.gallal2017@feps.edu.eg

Citation: Marina Adly Wahba et al., "Effect of Stock Market Development on Economic Growth: Case Study Egypt ", The International Journal of Public Policies in Egypt, IDSC, Volume (1), Issue (1), January 2022, pp. 92-115 


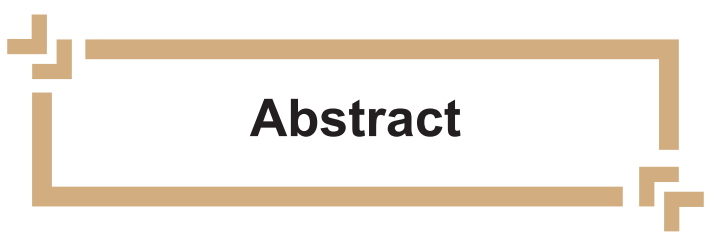

The growing importance of financial markets around the world renews the interest to investigate whether development of the stock market specifically can promote long-run economic growth or not. The objective of this study is to investigate the empirical relationship between Stock Market Development and Economic Growth in Egypt during the critical economic period of 2009 to 2019 which has experienced many economic and political events.

Following the literature, the study uses secondary data collected from the World Bank, International Financial Statistics (IFS), and the Egyptian Ministry of Planning (MoP) and Central Bank of Egypt (CBE) for stock market indicators, economic growth indicators, banking sector variables and other relevant macroeconomic variables. The quarterly data used to estimate the relationship through hybrid method (both quantitative and qualitative) approach. The qualitative part uses a graphical illustration to depict the evolution of various stock market variables while the quantitative part focuses on investigating the empirical effect of stock market development on economic growth using ARDL model.

The main findings of the study are as follows: 1 ) there is no relationship over the short run between Stock Market Development and Economic Growth, 2) The effect of Stock Market Development on Economic Growth is negative over the long run (holds only for the turnover ration), 3) The main triggers for Economic Growth in Egypt during this period are other factors like higher Primary Education enrolment, 4) There is no relation between the banking sector and the economic growth neither in the short run nor in the long run, 5) The results match with the literature of some developing countries, including Egypt. The negative relationship may be due to the underdeveloped financial systems., and 6)The results of the test are stable, robust and correctly specified.

Keywords: Economic Growth, Stock Market, M2, Market Capitalization, Trade Openness 


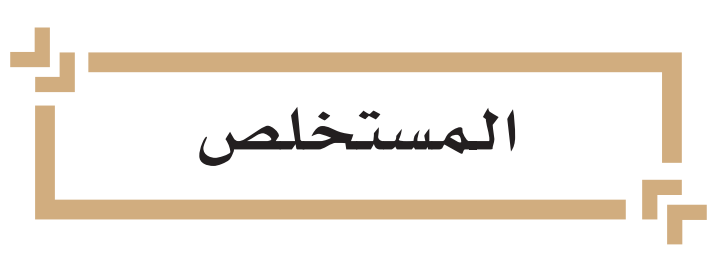

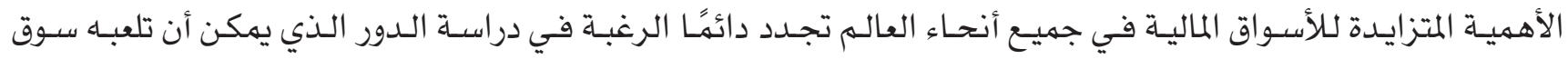

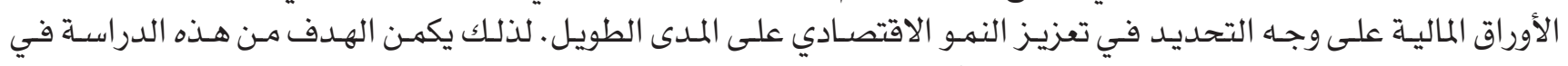

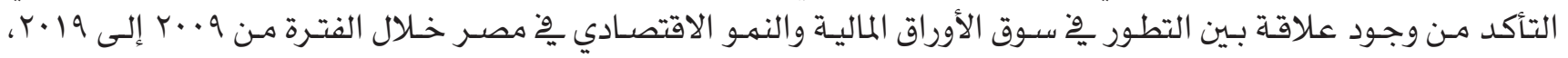

$$
\text { والتي شـهدت العديـد من الأحـداث الاقتصاديـة والسياسـية. }
$$

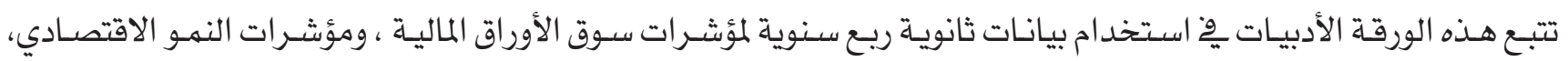

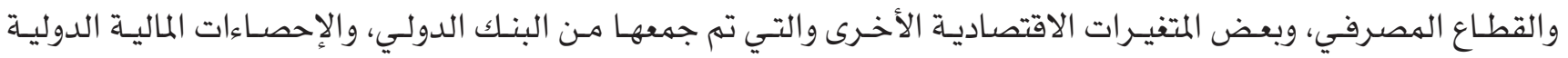

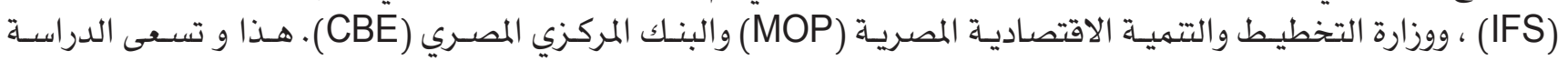

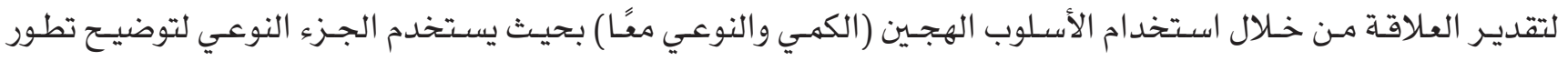

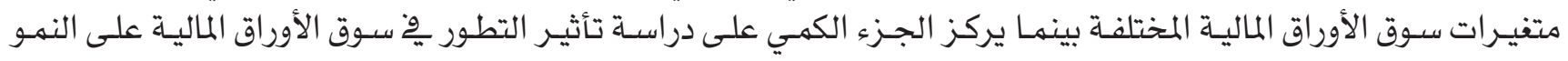

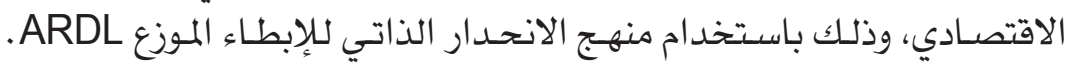

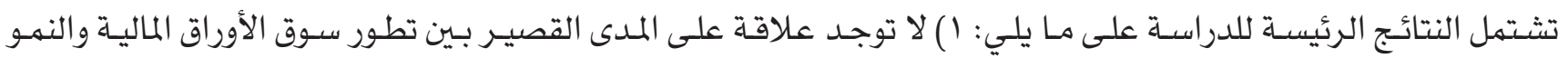

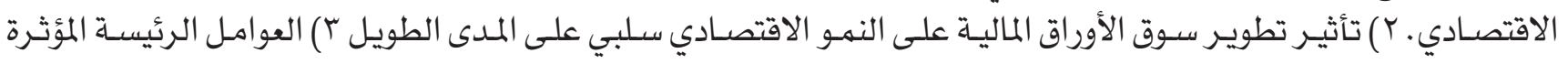

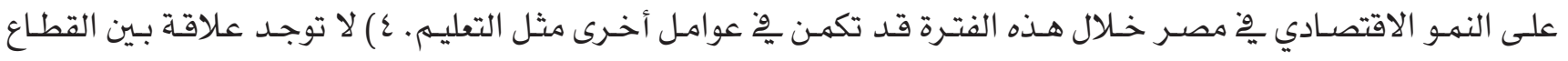

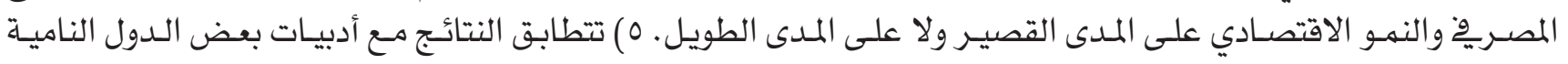

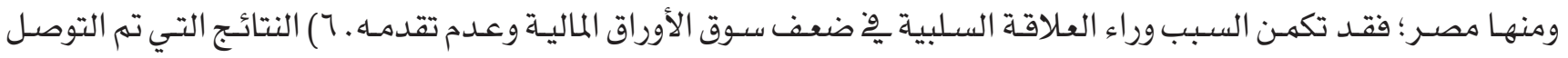
إليها قويـة ومستقرة. الكلمات المفتاحية: النمو الاقتصادي - سوق الأوراق المالية - M2، القيمة السوقية - الانقتاح التجاري 


\section{Introduction}

The stock market acts as a financial intermediary through allocating saving funds to mitigate the creditors' risks and enhance profitability by increasing the efficiency of financial intermediaries. It also provides investors with the opportunity to raise capital at reasonable costs away from credit market and thus escape from the issue of asymmetric information. This encourages companies to increase their investments, and hence improves the efficiency of resource allocation and thereby increasing economic growth (Mamun et al. 2018). To this end, national governments try to keep a close monitor and control on the activities of stock markets.

The growing importance of financial markets around the world renews the interest to investigate whether development of the stock market specifically can promote long-run economic growth or not. Traditional economists believe that there is no correlation between stock market and economic growth (Karki, 2016). However, a stream of research has begun to test this relationship deeply, starting by the pioneering work of Schumpeter (1911) and the works of McKinnon (1973) and Shaw (1973). However, others have found a negative impact for stock market on economic growth on the long run such as Pan and Mishra (2018). Knowing whether stock market development positively affects economic growth or not helps governments to reshape the financial sector and follow appropriate economic policies that support its economic growth. Accordingly, this paper is going to expand the literature and test the relationship between stock market development and economic growth in Egypt during the critical economic period of 2009 to 2019 which has experienced many economic and political events and to answer the following questions using both descriptive and econometric analysis: Does relationship exist between stock market development and economic growth in Egypt? If yes, is it positive or negative? Does it hold in the long-run?

The paper is organized as follows: Section 1 shows the literature and empirical review. Section 2 introduces an overview for stock market in Egypt and its development during the period 2009 till 2019. Section 3 highlights the methodology that is applied throughout the whole analysis performed. Section 4 visualizes the descriptive part of the stock market evolution. Section 5 explains the econometric model used. Section 6 pinpoints the main empirical findings. Then the conclusion is presented. 


\section{1- Literature Review}

\section{1-1 Theoretical framework}

The growing importance of stock market role all over the world has motivated a stream of research to examine the relationship between financial development and economic growth, more specifically the effect of stock market development on economic growth. The general idea that financial development is related to economic growth can be explained theoretically within the framework of endogenous growth models, which argue that economic growth is self-sustaining without exogenous technological progress and is influenced by initial economic variables from inside the economy. The development of financial markets is endogenous as they represent normal part of the process of economic growth (Barro \& Sala-i-Martin, 1995). Unlike the traditional growth theory that couldn't explain the relationship between the financial sector and economic growth, as it focuses on the steady state level of productivity not on the growth rate, the new framework of endogenous growth model explains this relationship by arguing that stock market development is a key element in fostering long-run economic growth. As it results in efficient allocation of resources, capital accumulation and technological innovation (Levine, 1997; Agarwal, 2001)

Mckinnon (1973) and Shaw (1973) have developed an important framework in literature to examine the relationship between financial development and economic growth. They show that financial market development is a key to economic growth and is significantly correlated with the level of per capita income. However, these two studies provide little analytical perspective to the outline of the role of stock markets, in fact Shaw argues that stock market development in early stages of development could be very costly to achieved for developing countries. Cho (1986) offers a more structural analysis of the role of stock market to the Mckinnon-Shaw framework by applying the theory of credit rationing that is introduced by Stiglitz and Weiss (1981). Cho argues that credit markets cannot work efficiently without stock market. His point of view can be summarized as follows: (i) the banking sector suffers from lack of information and cannot always achieve efficient allocation of capital in credit market. (ii) On the other hand, stock markets are free from adverse selection and moral hazard problems. Therefore, the expected return on equity investor would be the same as expected return from a project. (iii) Accordingly, the development of stock markets is rather a necessary condition for achieving financial liberalization.

Another strand of the literature examines the direction of causality between financial market development and economic growth (Colombage, 2009). A major problem concerning this issue is which variable precedes the other: Is financial growth a stimulus or motivator for economic growth or does economic growth energize and enhance the financial growth? There are four broad views in literature regarding the relationship between financial development and economic growth. These possible directions of 
causality between financial development and growth are labeled by as the supply-leading, demand following, support feedback hypothesis and finally the no causality relationship (Patrick, 1966).

The first and the most dominant view indicates that there is unidirectional causality relationship from stock market development to economic growth which is known as "supply-lending" view (Pradhan et al, 2014). Proponents to this view explain that financial intermediation result in economic growth through two main channels: (1) increasing the efficiency by which the capital is accumulated and (2) increasing the saving rate which results in raising the investment rate as well (Al-Yousif, 2002). In other words, the presence of a well-developed financial system reduces information and transaction costs and efficiently allocates capital, and thus promotes investment and technological innovation, and finally boosts economic growth (Levine \& Zervos, 1996; ACMA, 2020) The second view clarifies that the there is also a unidirectional relationship between both variables. However, unlike the first view, it suggests that the causality relation goes from economic growth to stock market development which is known as "demand-following" view (Pradhan et al, 2014). Economists who support the demand following view explains that the surge in demand for economic activities has called for expanding and creating financial services, institutions, and markets. This means that financial development follows the lead of economic growth (Nwagu, 2020).

The third view "support feedback hypothesis" believes that the relationship between financial development and economic growth is rather a bidirectional one (Hou, \& Cheng, 2010), thus, the causation runs in both directions simultaneously (Pradhan et al, 2014). Finally, the fourth view argues that there is no mutual relationship. Economists, who support this view, clarify that both financial development and economic growth are not causally related (Al-Yousif, 2002). Proponents of this view claim that economists badly overstress the role of financial factors in economic growth (Lucas Jr, 1988). Along this study, the focus is on the supply lending view. However, it is worth mentioning that the supply-leading finance neither imply that finance is a necessary condition nor a precondition for achieving or sustaining economic development. Rather, it presents an opportunity to induce and motivate real growth by financial means (Patrik,1996).

\section{1-2 Empirical Review:}

This section examines some of the related studies that focus on the relationship between stock market development and economic growth. Scholars do not reach consensus about the nature and direction of the relationship as the results depend on the model employed, type of data used in the analysis and the period of study (Paramati \& Gupta, 2011). Thus, empirical studies could be categorized into four groups. 
The first group is those studies that find a significant positive relationship between stock market development and economic growth as stock market development leads to economic growth. One of these studies is that of Arestis et al (2001). The paper has investigated the relationship between stock market development and economic growth, controlling the effects of banking system and stock market volatility by utilizing time varying quarterly data from five developed economies: France, Germany, Japan, the United Kingdom, and the United States for the time span of 1968 to 1998. The analysis is made using a vector autoregression (VAR) framework making use of the following variables: quarterly data on output and indicators of banking system development, stock market development and stock market volatility. Where, output is measured by the logarithm of real GDP; stock market development by the logarithm of the stock market capitalization ratio; banking system development by the logarithm of the ratio of domestic bank credit to nominal GDP; stock market volatility measured by an eightquarter moving standard deviation of the end-of-quarter change of stock market price. The empirical results argue that both stock markets and banks seem to play an important role in the promotion of output growth in France; Germany and Japan in both the short run and the long run. Yet, in the case of United States stock market development is positively related to real GDP and to banking sector development but in the long-run evidence suggest that financial development does not cause real GDP growth in the long run. Also, one of the main findings is that bank-based financial systems is able to promote long-term growth more than capital-market-based ones. Stock market volatility on the other hand has negative real effects in Japan, France, the United States and the United Kingdom.

The second group of studies tackles those who find that economic growth and stock market development reinforce each other or mutually causal. From these studies one is performed by Pradhan, Arvin, Hall, and Bahmani (2014). The study analyzes the relationship among banking sector development, stock market development, economic growth, and four other macroeconomic variables in 25 member countries of ASEAN regional forum (ARF) using annual time series data over the period of 1961-2012. The analysis considers four samples of countries. The first sample consists of 10 countries that are recognized as ARF-Member Countries (AMC), the second sample consists of 9 countries that are recognized as ARF-Dialogue Partner Countries (ADC), the third sample consists of 6 countries that are recognized as ARF-Observer Countries (AOC), and the fourth sample consists of all 26 countries (ATC) that were included in AMC, ADC, and AOC. The variables used in the study are banking sector development, stock market development, per capita economic growth (GDP), and a set of four other macroeconomic variables namely foreign direct investment, trade openness, inflation rate, and government consumption expenditure. Banking sector development is measured by broad money supply, claims on private sector, domestic credit provided by the banking sector, and domestic credit to the private sector. While stock market development is measured using market capitalization, 
percentage of change in the total value of traded stocks, turnover ratio, and the number of listed companies. The study relies on principal component analysis to construct the development indices and employs co-integration test to determine if there is a long-run equilibrium relationship among the variables in addition to panel vector auto-regressive model for testing the Granger causalities. Focusing only on stock market development and economic growth in the short run, the study finds for Dialogue Partner Countries (ADC) bidirectional causality between stock market development and economic growth while for the remaining three samples (AMC, AOC, ATC) unidirectional causality exists from stock market development to economic growth.

The third group of studies includes those who claims for negative relationship between stock market development and economic growth. Studies performed by Shleifer and Summers (1988), as well as Morck et al., (1990a) show that the stock market development could adversely affect economic growth of the country due to the fact that this kind of development would allow more counterproductive corporates to takeover. As some managers would rely on the stock market as the only source of information to make their decisions, which may or may not be correct about the future. For example, the takeover may happen due to low stock price. This low price prevents the top management from increasing investment in the firm due to the prospect of further erosion in the stock price. Also, Devereux and Smith (1994) mention the saving rates minimization potential that could occur as a result of greater risk sharing through internationally integrated stock markets, which would affect the economic growth negatively.

The fourth group of studies represent those who confirm the lack of significant relationship between stock market development and economic growth. A study was conducted by Naceur and Ghazouani (2007) using an unbalanced panel data from 11 MENA region countries over the period 1979-2003 in order to examine the relationship among stock markets, banks and economic growth. The variables used are the growth of real per capita GDP as a measure of economic growth, stock markets development measured by market capitalization to GDP ratio, value traded variable as a measure of liquidity and the turnover ratio to capture the efficiency of the domestic stock markets. The analysis is based on estimation of a dynamic panel model with the generalized method of moments estimators. The empirical results show no significant relationship between banking and stock market development, and growth. Therefore, further stock market development does not play a statistically significant role on stimulating further economic growth. This lack of relationship could be linked to underdeveloped financial systems in the MENA region that hamper economic growth. On another note, it is expected that empirical results may be a bit different for developing counties than developed countries, as they suffer from lack of a well-developed stock market. Thus, other empirical studies like Bencivenga and Smith (1991), Adajaski and Biekpe (2006) state that no significant relationship between stock market improvement and economic growth are recorded, especially in the case of developing countries. 


\section{2- Overview for stock market evolution}

\section{2-1 Evolution and Establishment of the Stock Market:}

Before 1989, there were only five stock markets existing in Sub Saharan Africa and three in North Africa. However, nowadays, there has been a significant development of capital markets in Africa as there are currently 19 stock exchanges that initiated from Uganda and Mozambique stock exchanges to the Nigeria and Johannesburg stock exchange markets between 1992 and 2002.

Alexandria witnesses the establishment of the first stock exchange in 1883 while Cairo's stock exchange dates back to 1903. In 1907, there was a significant increase in the number of listed companies as it reaches 228 with a market capital of about 91 million Egyptian pounds. However, post the 1952 Revolution and the move towards nationalization, the number of the listed companies decreased dramatically which affected the activity of the stock exchange until the government adopted economic reform and privatization programs. (Otaify, 2016)

The Capital Market Law was issued in 1992 , and there were subsequent regulations and decisions that leads to open the door again for revitalization of the Egyptian Exchange. Year after year, Improvements continues to take place in the form of activities and new institutions until the Egyptian Stock Exchange became one of the strongest in the region. (Otaify,2016)

\section{2-2 Evolution of the Stock Markets in Egypt during (2009-2019)}

The period of 2009 till 2019 witnessed many important national and international events that have affected the Egyptian Stock Exchange such as: the global financial crisis of 2008, the 25th of January 2011 Revolution, the 30th of June 2013 Revolution, the floatation of the Egyptian pound, and the Economic reform program of 2016. In response, the Government and authorities had taken corrective actions to mitigate the effects of these events on the stock market. There were great efforts directed towards restructuring the Over the Counter (OTC) market during this period to improve investment climate for non-listed companies. It is worth mentioning that during the period of 2009 to 2019 EGX has made intensive external and internal promotional campaigns to restore confidence in the Egyptian Market, which increased the number of newly coded investors as well as the listed companies. From 2009 till 2019, EGX launched a set of new indices, namely, EXG 70, EGX 100, and EGX 20 Capped Index. (EGX, various issues)

Despite the recession of 2008, Egypt witnessed a number of improvements in 2009 especially in the EGX front, namely, the establishment of the Egyptian Financial Supervisory Authority (EFSA), which merged many entities together with the financial leasing, factoring and securitization activities under one entity. This year has also witnessed a number of technological developments, such as the signature of EGX on an agreement with London Stock exchange (LSE) to connect the two markets via 
FIX connectivity system. This provided EGX access to more liquidity and made it the hub in the Middle East and Africa region (EGX, 2009). The year 2009 witnessed a rising penetration of foreign investors into the Egyptian market with a large influx of investments (EGX, 2009).

The Egyptian stock market has passed many laws and decrees that regulate it, but one of the main decrees that is related to the study period is the presidential decree No. 121 of 2009 regarding the management of the Egyptian Stock Exchange and its financial affairs. This decree has been amended several times during the study period. The decree gives EGX the right to participate in establishing companies and identify the three main resources of the Egyptian stock market. The Nile Stock Exchange was introduced to represent the small and medium-sized companies that are listed in the stock exchange (Egypt's Presidency, 2009)

During the early days of the 25th of January Revolution in 2011, EGX was forced to suspend trading until things become more stable. The political instability occurred during and after the revolution affected the economic and financial climate negatively. All stock market indices experienced and the Egyptian participation steep declines due to the revolution outbreak and the political instability that the country had faced at that time (Ahmed, 2016). So, it was necessary to take precautionary measures to protect the market after re-opening. These measures encompass the amendment of the price limits on the listed shares and the suspension of intra-day trading.

In 2016, the government had launched the Economic Reform Program which aimed at regaining the economic stability. During that time, Egyptians had grown confidence in the market after the liberalization of the currency which had affected their decisions to participate in the Egyptian stock market, especially after IMF approved a three-year loan of USD 12 billion in order to restore the macroeconomic stability and promote inclusive growth (IMF, 2019).

From 2017 to 2019, Egypt had witnessed a lot of industrial, touristic, infrastructural and road projects as well as investments in the country as the Suez Canal and Ras Ghareb Wind Farm. Those all had been reflected in the foreign participation in the Egyptian stock market which had boomed compared to the previous years. Also, during this period there were some amended laws that have been implemented such as the amendment of 2018 which allow stock split more than once per stock per year, expanding price limits for companies that subject to tender offers with a price outside price limit, and reducing trading halt time from 15 minutes to 10 minutes (EGX, 2018). Also, in 2019, the short-selling mechanism was activated, such mechanism was initially issued in 2004, but was not yet activated (EGX, 2019). All these decrees aimed at facilitating decision making and the functioning of the stock market, as well as enhancing its independence and transparency and enhancing liquidity. 


\section{3- Methodology}

The present study depends on secondary data collected from the World Bank, International Financial Statistics (IFS), The Egyptian Ministry of Planning (MOP) and Central Bank of Egypt (CBE). The time series data for Egypt is collected from 2009 till 2019 for stock market indicators, economic growth indicators, banking sector variables and other relevant macroeconomic variables. Following the literature, the following table highlights the definition of variables used, the indicators and its source.

Table 1 Definition of the variables used in the study and there source.

\begin{tabular}{|c|c|c|c|}
\hline Variable & Indicators & Definition & Source \\
\hline \multirow[t]{2}{*}{ Stock Market } & $\begin{array}{c}\text { 1-Stock Market } \\
\text { Capitalization }\end{array}$ & $\begin{array}{l}\text { It is defined as the market price at end of } \\
\text { year times the number of shares } \\
\text { outstanding of the domestic listed } \\
\text { companies. } \\
\text { It is calculated as a percentage of GDP at } \\
\text { the end of the year }\end{array}$ & CBE \\
\hline & $\begin{array}{l}\text { 2-Turnover ratio of } \\
\text { stocks traded }\end{array}$ & $\begin{array}{l}\text { It is calculated by the researchers as the } \\
\text { total value of domestic securities traded } \\
\text { divided by their market capitalization. }\end{array}$ & $\mathrm{CBE}$ \\
\hline $\begin{array}{l}\text { Economic } \\
\text { Growth }\end{array}$ & GDP growth rate & $\begin{array}{l}\text { It is calculated by the researchers as the } \\
\text { annual percentage growth rate of the } \\
\text { quarterly the real GDP based on } \\
\text { expenditure approach using market prices } \\
\text { and constant prices for the base year } \\
2016 / 2017\end{array}$ & MOP \\
\hline Banking Sector & Ratio of M2 to GDP & $\begin{array}{l}\text { It is calculated by the researchers where } \\
\text { M2 is calculated by the CBE as money } \\
\text { supply plus quasi-money. }\end{array}$ & CBE \\
\hline $\begin{array}{l}\text { Extent of } \\
\text { integration with } \\
\text { the rest of the } \\
\text { world }\end{array}$ & Trade Openness & $\begin{array}{l}\text { It is the trade of goods and services as a } \\
\text { percentage of GDP in which trade is } \\
\text { calculated as the sum of exports and } \\
\text { imports of goods and services measured as } \\
\text { a share of gross domestic product. }\end{array}$ & $\begin{array}{l}\text { World } \\
\text { Bank }\end{array}$ \\
\hline $\begin{array}{l}\text { Human Capital } \\
\text { Formation }\end{array}$ & $\begin{array}{l}\text { Gross Primary } \\
\text { enrollment ratio }\end{array}$ & $\begin{array}{l}\text { It is the ratio of total enrollment, } \\
\text { regardless of age, to the population of the } \\
\text { age group that officially corresponds to the } \\
\text { level of education }\end{array}$ & $\begin{array}{l}\text { World } \\
\text { Bank }\end{array}$ \\
\hline
\end{tabular}

This study applies both quantitative and qualitative approach to investigate the relation between stock market and economic growth in Egypt in the period from 2009 till 2019. On the qualitative side, graphical illustration is applied to depict the evolution and trend of various stock market variables. On another front, the quantitative part focuses on investigating the empirical effect of stock market development on economic growth taking into consideration the other macroeconomic variables that may affect the economic growth. To carry out time series analysis, unit root tests are performed. Depending on the results of ADF test, the study employs the ARDL approach. Moreover, the ARDL model is preferred as it is suitable for small samples sizes in addition to providing unbiased estimates and statistically significant t-statistics in the long term (Elhassan \& Braima, 2020). 


\section{4- Descriptive Analysis}

Figures 1 and 2 examine both the evolution of the market capitalization to GDP and the GDP growth rate in Egypt and that of the shares turnover ratio with the GDP growth rate respectively. The market capitalization ratio of the GDP reflects the economic significance of stock market in the national economy and therefore researchers usually use this variable and the shares turnover ratio as a proxies of the stock market development and the GDP growth is used as a proxy for the economic growth (Otaify, 2016).

From both graphs it is obvious that: the GDP growth rate has reached one of its highest rates in Q1 2010. This has been driven by the increase in domestic consumption and the positive contribution of external demand. This is in addition to tourism that has shown solid growth and the Suez Canal revenues that has shown some signs of slow recovery. In addition to that, the turnover ratio increased significantly from 5\% in Q1 of 2009 to almost 12\% in Q4 2011 which made the stocks more attractive for the foreigners to invest in Egypt as it reflects the increasing activity over the listed stocks. As a result, the Foreign Participation percentage from the Total Traded Securities Value increased from $22 \%$ to $29 \%$. (World Bank, 2010). During 2011, the GDP has suffered from a lot of fluctuations due to the political and economic instability prevailing during this time. Such instability took its toll on the stock market as well. The number of newly listed shares have declined to reach 213 by 2011 and the total value traded of stocks has plunged to reach EGP 148 billion also market capitalization to GDP has declined to reach its minimum at $41 \%$ this was partly caused due to closing the EGX around 55 days after the revolution. That was also reflected on the Turnover Ratio, as it reaches its highest value in the second quarter of 2013 that is $16.15 \%$ to be also reflected positively on the Foreign Participation Percentage in relation to 2012 and 2014 (Figure 1) (EGX, 2011). The market capitalization to GDP has increased in Q4 2016, the year in which The Economic Reform Program launched; this was was partly due to stability of the global economy and the new amendments to the listing rules which has led to increasing number of the listed companies to reach 222 companies (EGX, 2016). Then from 2017 to 2019, the Stock Turnover ratio begins to decline, especially from Q4 2016 up till the end of 2019. The values of the Turnover Ratio are just around the mean of $9 \%$ of the Market Capitalization. However, the greatest increase in the Market Capitalization to GDP has taken place in Q1 2018, this was mainly triggered by the new EGX amendments and rules which had worked on motivating investors to regain trust in the market (EGX, 2018). The graphical illustration presented above fails to capture any clear pattern of relation between stock market development and economic growth 
Figure 1 GDP Growth Rate and Market Capitalization (\% of GDP). (2009-2019)

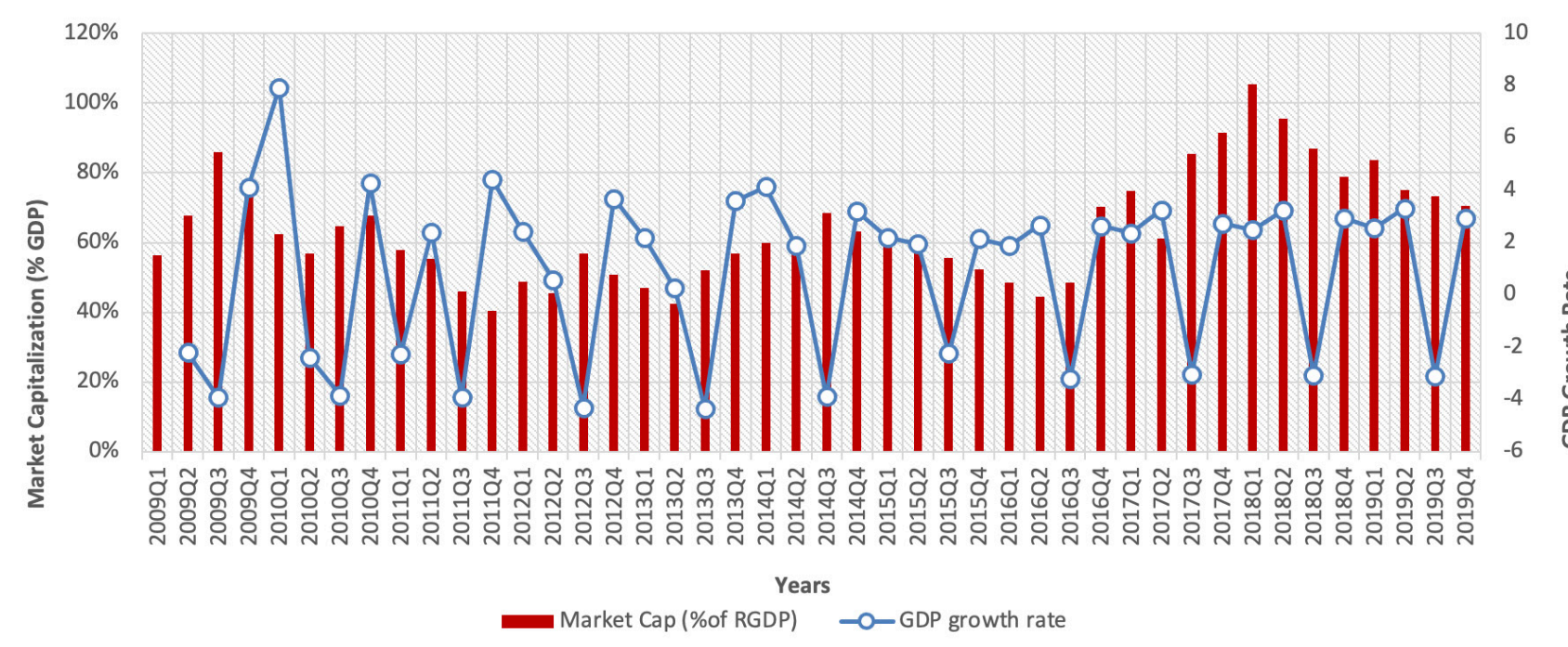

Source: Researcher's Formulation according to CBE reports and Ministry of Planning reports.

Figure 2 Real GDP Growth Rate and Stock Turnover Ratio (2009-2019)

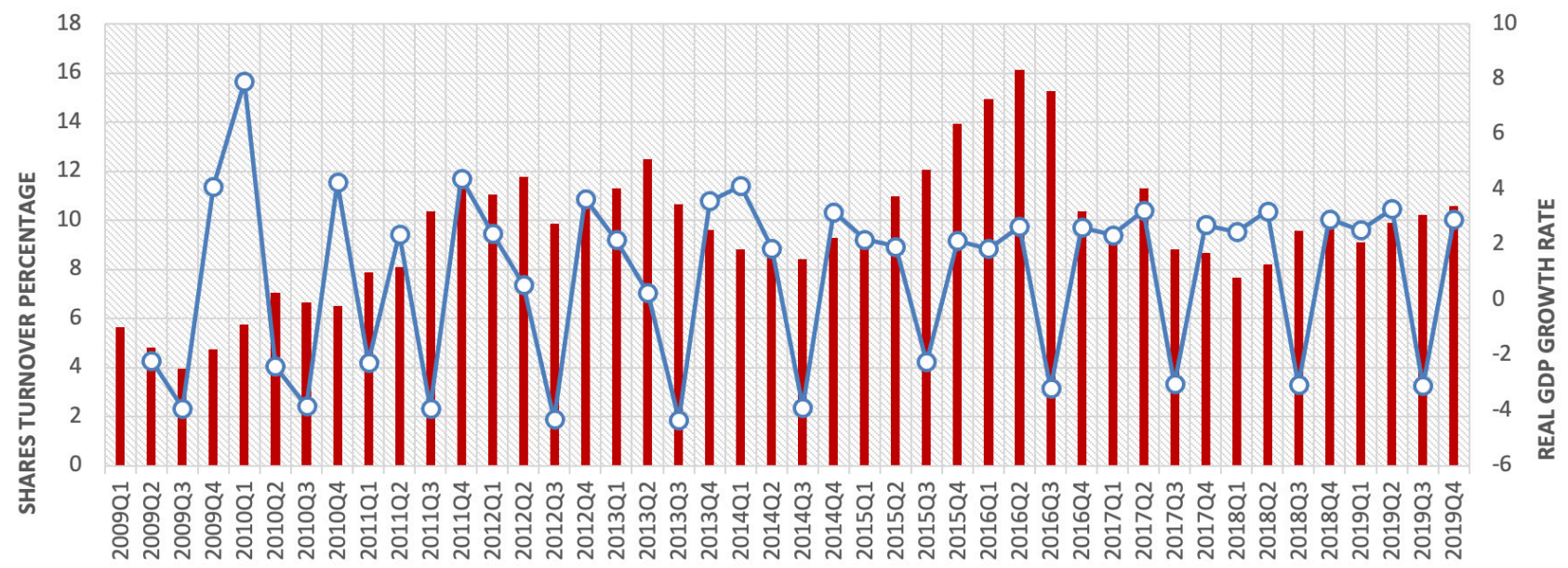

- TURNOVER RATIO (OF SHARES) ——REAL GDP GROWTH RATE

Source: Researcher's Formulation according to CBE reports and Ministry of Planning reports. 


\section{5- Quantitative Analysis}

\section{5-1 Unit Root Test:}

First, the study employs the ADF stationary test to examine the stationarity of the time series for the variables used and to make sure that none of them is stationary at second difference. The ADF test results show that Real GDP Growth Rate variable is stationary at their level. According to the ADF results in Table 2, as the P-value is $\leq 0.05$ the null hypothesis of having a unit root (non-stationary) is rejected for these variables at the $1 \%, 5 \%, 10 \%$ significance levels. The table also pinpoints that Stock Turnover Rate (\%Real GDP), Trade Openness (\%Real GDP), Market Capitalization (\%Real GDP), and M2 (\%Real GDP), Primary Education Enrollment Rate, variables are all stationary at the first level of difference. None of the variables is stationary at the second difference which allows for the employment of the ARDL approach.

Table 2:Summary for the results of ADF Test for stationarity

\begin{tabular}{|l|c|c|c|c|}
\hline \multicolumn{1}{|c|}{ Variable } & Abbreviation & t-statistic & ADF Test (P-value) & Decision \\
\hline Real GDP Growth Rate & GRGDP & -3.586477 & 0.0000 & $\mathrm{I}(0)$ \\
\hline M2 & M2 & -7.376696 & 0.000 & $\mathrm{I}(1)$ \\
\hline Primary Education & PI & -5.378035 & 0.0001 & $\mathrm{I}(1)$ \\
\hline Market Capitalization & MCAP & -6.292906 & 0.000 & $\mathrm{I}(1)$ \\
\hline Stock Turnover Ratio & TR & -5.529848 & 0.0000 & $\mathrm{I}(1)$ \\
\hline Trade Openness & TRD_OP & -2.101369 & 0.0357 & $\mathrm{I}(1)$ \\
\hline
\end{tabular}

Source: authors' analysis based on the findings of the ADF test.

\section{5-2 ARDL Bounds Test:}

Depending on the results of ADF test, the study employs the ARDL approach; the ARDL approach provides unbiased estimates and statistically significant t-statistics in the short term even when some of the regressors are endogenous (Odhiambo, 2011). The ARDL approach is applied as follows: after the unit roots test, the long-term and short-term models are estimated by the bounds test and error correction model (ECM). The decision is made depending on the F-statistic value as if it is the upper bound critical value or larger, the null hypothesis of having no cointegration (no long run relationship) is rejected. If the computed F-statistics is less than the lower bound critical value, this means that the null hypothesis of cointegration cannot be rejected. But in case the computed test F-statistics value falls within the lower and upper bound critical values, the decision will be inconclusive.

An ARDL bounds test is specified as follows:

$$
\text { GRGDP = } \beta 1 \text { PIt }+\beta 2 \text { M2t }+\beta 3 \text { MCAPt }+\beta 3 \text { TRt }+\beta 4 \text { TRD_OP } t+\varepsilon t
$$

Where the main hypothesis is as follows:

$$
H 0: \beta 1=\ldots \ldots . .=\beta 8 \text { indicating that there is no cointegration }
$$

$$
H 1: \beta 1 \neq \ldots \ldots \ldots \neq \beta 8 \text { indicating that there is a cointegration }
$$




\section{6- Empirical Findings:}

This section shows the empirical findings. The ARDL model is estimated using Restricted, Constant trend specification with maximum lags $=4$ for both the dependent variable and the regressors where the model selection criteria selected is Akaike Information Criterion (AIC), while the Ordinary option is selected for the Coefficient Covariance matrix.

The R-squared value for the estimated ARDL model in table (14) in the appendix is 0.944020 meaning that approximately $94 \%$ of the variance in real GDP growth rate is explained by the incorporated independent variables in the model which indicates overall goodness-of-fit for the model. Considering the F-bound test results in Table (3), the F-statistic is greater than the upper bound with all significance levels, so the null hypothesis of no cointegration is rejected which means that there is long run relationship between the variables at $1 \%$ significance level; therefore, the results of the model can be used and the model is robust.

Table 3 F-Bounds test results

\begin{tabular}{||lcccr||}
\hline \hline & \multicolumn{4}{c||}{ Null Hypothesis: No levels relationship } \\
\hline \hline Fest Statistic & Value & Signif. & $\mathrm{l}(0)$ & $\mathrm{I}(1)$ \\
\hline \hline & & \multicolumn{4}{c}{ Asymptotic: $\mathrm{n}=1000$} \\
F-statistic & 38.23185 & $10 \%$ & 2.08 & 3 \\
k & 5 & $5 \%$ & 2.39 & 3.38 \\
& & $2.5 \%$ & 2.7 & 3.73 \\
& & $1 \%$ & 3.06 & 4.15 \\
Actual Sample Size & 40 & & & Finite Sample: $\mathrm{n}=40$ \\
& & $10 \%$ & 2.306 & 3.353 \\
& & $5 \%$ & 2.734 & 3.92 \\
& & $1 \%$ & 3.657 & 5.256 \\
\hline \hline
\end{tabular}

Source: authors' analysis based on the findings of the ARDL approach.

\section{6-1 Short-term error correction:}

The short-term results of the ARDL are depicted in Table (4) and Table (15) in the appendix. It shows that (i) primary education enrolment, the proxy for human capital formation, is statistically significant in the short-run at 0.05 significance level, hence when primary education enrolment increases by $1 \%$ real GDP growth rate increases by $2.206 \%$. (ii) All other variables, including market capitalization and turnover ratio, are insignificant in the short-run as their $p$-value is greater than 0.05 . These results support the previous findings by Bencivenga and Smith (1991), Adajaski and Biekpe (2006) and Naceur and Ghazouani (2007), who state that no significant relationship between stock market improvement and economic growth are recorded, especially in the case of developing countries. On the other hand, these results are in contrast to those of Elhassan and Braima (2020), who demonstrate that market capitalization and turnover ratio are significant in the short-run and have a negative impact on economic growth in Sudan. 
Table 4 Short run effects of ECM test

\begin{tabular}{|c|c|c|c|c|}
\hline \multicolumn{5}{|c|}{ Conditional Error Correction Regression } \\
\hline Variable & Coefficient & Std. Error & t-Statistic & Prob. \\
\hline C & -55.02691 & 17.76151 & -3.098098 & 0.0069 \\
\hline GRGDP $(-1)^{*}$ & -3.926090 & 0.258897 & -15.16467 & 0.0000 \\
\hline PI $(-1)$ & 0.793002 & 0.217821 & 3.640620 & 0.0022 \\
\hline TRD_OP(-1) & -0.287549 & 0.087959 & -3.269111 & 0.0048 \\
\hline $\mathrm{MCA} P(-1)$ & 0.004527 & 0.089607 & 0.050516 & 0.9603 \\
\hline TR(-1) & -1.456486 & 0.603879 & -2.411883 & 0.0282 \\
\hline M2(-1) & 0.005735 & 0.011619 & 0.493604 & 0.6283 \\
\hline $\mathrm{D}(\mathrm{GRGDP}(-1))$ & 1.872430 & 0.173713 & 10.77889 & 0.0000 \\
\hline D(GRGDP(-2)) & 0.949264 & 0.095535 & 9.936259 & 0.0000 \\
\hline $\mathrm{D}(\mathrm{PI})$ & 2.206282 & 0.344778 & 6.399132 & 0.0000 \\
\hline D(TRD_OP) & 0.043086 & 0.228607 & 0.188470 & 0.8529 \\
\hline $\mathrm{D}(\mathrm{TRD} \overline{\mathrm{O}} \mathrm{P}(-1))$ & 0.153843 & 0.235263 & 0.653919 & 0.5225 \\
\hline D(TRD_OP(-2)) & -0.317618 & 0.248466 & -1.278315 & 0.2194 \\
\hline$D(M \overline{C A P})$ & 0.128464 & 0.106236 & 1.209233 & 0.2441 \\
\hline $\mathrm{D}(\mathrm{MCAP}(-1))$ & -0.027849 & 0.087673 & -0.317644 & 0.7549 \\
\hline $\mathrm{D}(\mathrm{MCAP}(-2))$ & -0.061631 & 0.080808 & -0.762679 & 0.4568 \\
\hline $\mathrm{D}(\mathrm{TR})$ & 0.212933 & 0.572414 & 0.371992 & 0.7148 \\
\hline $\mathrm{D}(\mathrm{TR}(-1))$ & 0.614786 & 0.692005 & 0.888413 & 0.3875 \\
\hline $\mathrm{D}(\mathrm{TR}(-2))$ & 0.086705 & 0.703269 & 0.123289 & 0.9034 \\
\hline $\mathrm{D}(\mathrm{TR}(-3))$ & 0.330296 & 0.276873 & 1.192951 & 0.2503 \\
\hline $\mathrm{D}(\mathrm{M} 2)$ & 0.009039 & 0.016793 & 0.538238 & 0.5978 \\
\hline $\mathrm{D}(\mathrm{M} 2(-1))$ & 0.002570 & 0.014614 & 0.175859 & 0.8626 \\
\hline $\mathrm{D}(\mathrm{M} 2(-2))$ & 0.038588 & 0.014961 & 2.579204 & 0.0202 \\
\hline $\mathrm{D}(\mathrm{M} 2(-3))$ & 0.048121 & 0.017021 & 2.827138 & 0.0121 \\
\hline
\end{tabular}

Source: authors' analysis based on the findings of the ARDL approach.

\section{6-2 Estimation of Long Run coefficient:}

Table 5 shows the long run relation between stock market development (market capitalization and turnover ratio) and economic growth (real GDP growth rate). The MCAP is statistically insignificant at 0.05 level of significance meaning that the MCAP does not affect the economic growth in the long term as well as the short run. This is contradicting with the findings of Osaseri and Osamwonyi (2019) and Rezina (2017).

Table 5 Long run results for the ECM Test

\begin{tabular}{||crrrr||}
\hline \multicolumn{5}{||c||}{ Levels Equation } \\
\hline \hline Variable & Coefficient & Std. Error & t-Statistic & Prob. \\
\hline \hline PI & 0.201983 & 0.054932 & 3.676982 & 0.0020 \\
TRD_OP & -0.073241 & 0.023095 & -3.171322 & 0.0059 \\
MCAP & 0.001153 & 0.022808 & 0.050550 & 0.9603 \\
TR & -0.370976 & 0.157484 & -2.355640 & 0.0316 \\
M2 & 0.001461 & 0.002973 & 0.491306 & 0.6299 \\
C & -14.01570 & 4.362275 & -3.212934 & 0.0054 \\
\hline \hline EC = GRGDP - (0.2020*PI & $-0.0732^{*}$ TRD_OP + 0.0012*MCAP -0.3710*TR + \\
0.0015*M2 - 14.0157) & & & \\
\hline \hline
\end{tabular}

Source: authors' analysis based on the findings of the ARDL approach.

Also, M2 is not significant at 0.05 level of significance which clarifies that there is no relation between the banking sector and the economic growth neither in the short run nor in the long run. Although the turnover ratio in not significant in the short run, it becomes statistically significant in the long run and negatively related to the economic growth, so a $1 \%$ increase in the turnover ratio results in $0.37 \%$ decrease in economic growth. These results contradict with those of Elhassan and Braima (2020) who found that there is no long run relationship between the turnover and economic growth. Nevertheless, the reports results are consistent with that of Rezina (2017) and Ishioro (2013) who demonstrate that 
there is a negative relationship between the economic growth and turnover. The primary education appears to be significant in both the short and long run at 0.05 significance level, so a $1 \%$ increase in the primary education would increase the economic growth by $0.20 \%$. Unlike the short run results, trade openness in the long run turns to be significant as its $p$-value is less than 0.05 . It is apparent that there is a negative relationship between the trade openness and the economic growth so that a $1 \%$ increase in the trade openness would result in decreasing the economic growth by $0.07 \%$.

\section{6-3 Stability and Heteroskedasticity Tests:}

\section{Table 6 Ramsey RESET test results.}

\begin{tabular}{||lccc|}
\hline \multicolumn{1}{|l|}{ Ramsey RESET Test } \\
Equation: UNTITLED \\
Omitted Variables: Squares of fitted values \\
Specification: GRGDP GRGDP(-1) GRGDP(-2) GRGDP(-3) PI PI(-1) \\
TRD_OP TRD_OP(-1) TRD_OP(-2) TRD_OP(-3) MCAP MCAP(-1) \\
MCAP(-2) MCAP(-3) TR TR(-1) TR(-2) TR(-3) TR(-4) M2 M2(-1) M2( \\
M2(-3) M2(-4) C & & & \\
\hline \hline \multicolumn{5}{|c}{ Value } & df & Probability \\
t-statistic & 0.128140 & 15 & 0.8997 \\
F-statistic & 0.016420 & $(1,15)$ & 0.8997 \\
Likelihood ratio & 0.043762 & 1 & 0.8343 \\
\hline \hline
\end{tabular}

Table 7 Breusch-Pagan-Godfrey Heteroskedasticity test results

\begin{tabular}{|c|c|c|c|}
\hline \multicolumn{4}{|c|}{$\begin{array}{l}\text { Heteroskedasticity Test: Breusch-Pagan-Godfrey } \\
\text { Null hypothesis: Homoskedasticity }\end{array}$} \\
\hline F-statistic & 1.652429 & Prob. $F(23,16)$ & 0.1519 \\
\hline ObsR-squared & 28.14944 & Prob. Chi-Square(23) & 0.2102 \\
\hline Scaled explained SS & 4.702839 & Prob. Chi-Square(23) & 1.0000 \\
\hline
\end{tabular}

Source: authors' analysis based on empirical findings.

Ramsey RESET test is performed to check the stability of the test with null hypothesis stating that there is correct specification in the model. In Table (6) the value of both t-statistic and F-statistic is greater than 0.05 , so with $95 \%$ confidence level the null hypothesis is not rejected indicating that the used model is stable and correctly specified.

To check that the homoskedasticity assumption is not violated in the used model which may affect the results of the model, Breusch-Pagan-Godfrey Heteroskedasticity test is performed and the results is showed in Table (7). The results indicate that with $95 \%$ confidence level, the null hypothesis of homoskedasticity (equal error variances) is not rejected meaning that the results of this model can be used.

\section{Conclusion}

The aim of this study is to investigate the empirical relation between stock market development and economic growth in Egypt over both the short-run and long-run. This relationship is examined throughout the period 2009-2019 using both qualitative and quantitative analysis. The descriptive analysis shows that there is no obvious relationship between stock market development and the GDP growth rate which is a proxy for Economic Growth. While, the quantitative analysis is performed using ARDL model. The main variables used in the analysis are Market capitalization to GDP and the 
turnover ratio to proxy stock market development, growth rate of real GDP to proxy economic growth, the ratio of M2 to GDP to represent the banking sector, trade openness which measures the extent of integration with the rest of the world, and Gross Primary School Enrolment rate which proxies human capital formation. The findings of the model indicate that the performed model is stable and its results are valid and robust. The main results are as follows: a long run relationship exists between real GDP growth rate and stock market development (holds only for the turnover ratio), human capital formation, and trade openness. Both the turnover ratio and trade openness affect the economic growth negatively, in contrast to primary education that affects the economic growth positively. In the short run, the only significant variable is the primary education that has the same positive effect on economic growth as in the long run, while the rest of the variables are insignificant. So, the empirical findings claim that economic growth is not always derived from stock market indicators as market capitalization or turnover ratio. Briefly, the stock market development has no relationship with economic growth in Egypt in the short run, while in the long run it can affect the economic growth negatively. This conclusion follows the literature of some developing countries, including Egypt, like the results of no relationship that is concluded by Naceur and Ghazouani (2007) in the MENA region due to the underdeveloped financial systems. This result is an alarm for decision makers to try to work on removing any challenges that hinder the development of the stock market so as to reap its real potential benefits.

\section{References}

- Agarwal, S. (2001). Stock market development and economic growth: Preliminary evidence from African countries. Journal of Sustainable Development in Africa, 3(1).

- Ahmed, W. (2016). The dynamic linkages among sector Indices: The case of the Egyptian Stock Market. International Journal of Economics and Finance, 8(4).

- Al-Yousif, Y. K. (2002). Financial development and economic growth: another look at the evidence from developing countries. Review of financial economics, 11(2).

- Arestis, P. et al. (2001). Financial Development and Economic Growth: The Role of Stock Markets. Journal of Money, Credit, and Banking.

- Bahadur, s., \& Neupane, s. (2006). Stock market and economic development: a causality test. The Journal of Nepalese Business Studies, vol. 3, no. 1.

- Barro, R., \& Sala-i-Martin, X. (1995). Economic growth, New York, McGrow-Hill.

- Cho, Y. J. (1986). Inefficiencies from financial liberalization in the absence of well-functioning equity markets. Journal of Money, Credit and Banking, 18(2).

- Colombage, S. R. (2009). Financial markets and economic performances: Empirical evidence from five industrialized economies. Research in International Business and Finance, 23(3). 
- Economy of Egypt. Fanack.com. (2021, May 10). https://fanack.com/egypt/economy-of-egypt/.

- Egypt Presidency. (2009, February). Egyptian Presidential decree regarding the provisions governing the management of the Egyptian Stock Exchange and its financial affairs, The periodical bulletin of the - Egyptian Tax Association 20(77), pp. 335-340. Retrieved from http://search.mandumah.com/ Record/121314

- Egypt, Presidency. (2014, February 10). Amendments to Presidential Decree number 191 regarding Egyptian Stock Exchange. Al-Ahram Gate (6), 2-3. Retrieved from https://gate.ahram.org.eg/ News/455554.aspx

- Egyptian Tax Association. (2018, February). Important presidential decrees in 2017. The periodical bulletin of the Egyptian Tax Association, 28(109). Retrieved from http://search.mandumah.com/ Record/892181

- Egyptian Stock Exchange (EGX), annual reports, various issues.

- Elhassan, T., \& Braima, B. (2020). Impact of Khartoum Stock Exchange Market Performance on Economic Growth: An Autoregressive Distributed Lag ARDL Bounds Testing Model. MDPI Economies.

- Ellis Chukwumerije Nwagu ACMA, C. G. M. A. (2020). Research on the Impact of Stock Market Development on Real Economic Growth in Nigeria.

- Hou, H., \& Cheng, S. Y. (2010). The roles of stock market in the finance-growth nexus: time series cointegration and causality evidence from Taiwan. Applied Financial Economics, 20(12).

IMF 2019, Egypt: A path forward for economic prosperity, July 2019

- Ishioro, B. O. (2013). Stock market development and economic growth: Evidence from Zimbabwe. Ekonomska misao i praksa, (2)

- Levine, R. (1997). Financial development and economic growth: views and agenda. Journal of economic literature, 35(2).

- Levine, R., \& Zervos, S. (1996). Stock market development and long-run growth. The World Bank Economic Review, 10(2).

- Levine, R., \& Zervos, S. (1998). Stock Markets, Banks and Economic Growth. American Economic Review, 88(3).

- Lucas Jr, R. E. (1988). On the mechanics of economic development. Journal of monetary economics, 22(1).

- Massa, I. (2009). Stock markets in Africa: Bidding for growth amid global turmoil. London: Overseas Development Institute.

- McKinnon, R I (1973). Money and Capital in Economic Development, Washington, D.C., The Brookings Institution.

- Naceur, S., \& Ghazouan, S. (2007). Stock markets, banks, and economic growth: Empirical evidence from the MENA region. Research in International Business and Finance. 
- Nishat, M. et al. (2004). Macroeconomic factors and the Pakistani equity market [with Comments]. The Pakistan Development Review.

- Nkoro, E., \& Uko, A. (2016). Autoregressive Distributed Lag (ARDL) cointegration technique: application and interpretation. Journal of Statistical and Econometric Methods, vol.5, no.4.

- Odhiambo, Nicholas M. 2011. Financial Intermediaries Versus Financial Markets: A South African Experience. International Business \& Economics Research Journal (IBER) 10.

- OECD, (2018), Compact for Economic Governance Stocktaking Report: Egypt https://www.oecd.org/ mena/competitiveness/Compact-for-Governance-Stocktaking-Report-Egypt-2018-EN.pdf

- Osaseri, G., \& Osamwonyi, I. O. (2019). Impact of stock market development on economic growth in BRICS. International Journal of Financial Research, 10(1).

- Otaify, M. (2016). Egyptian Stock Exchange: Analysis of Performance \& Activity. Available at SSRN 3599555.

- Paramati, s., \& Gupta, R. (2011). An Empirical Analysis of Stock Market Performance and Economic Growth: Evidence from India. International Research Journal of Finance and Economics.

- Patrick, H. T. (1966). Financial development and economic growth in underdeveloped countries. Economic development and Cultural change, 14(2), 174-189.

- Pradhan, R. P., Arvin, M. B., \& Bahmani, S. (2015). Causal nexus between economic growth, inflation, and stock market development: The case of OECD countries. Global Finance Journal, 27.

- Pradhan, R. P. et al. (2014). Causal nexus between economic growth, banking sector development, stock market development, and other macroeconomic variables: The case of ASEAN countries. Review of Financial Economics, 23(4).

- Reddy Paramati, Sudharshan, and Rakesh Gupta. "An Empirical Analysis of Stock Market Performance and ..." Http://Www.eurojournals.com/Finance.htm, International Research Journal of Finance and Economics, 2011, research- repository.griffith.edu.au/bitstream/handle/10072/44055/77258_1. pdf?sequence=1.

- Rezina, et al. (2017). Contribution of Stock Market Towards Economic Growth: An Empirical Study on Bangladesh Economy. European Scientific Journal, ESJ, 13(4).

- Shaw, E. S. (1973). Financial deepening in economic development. New York, N.Y. (USA) Oxford Univ. Press

- Stiglitz, J. E., \& Weiss, A. (1981). Credit rationing in markets with imperfect information. The American economic review, 71(3).

World Bank. 2010. Egypt Economic Update, Fall 2010. Washington, DC. (C) World Bank. https:// openknowledge.worldbank.org/handle/10986/27775 License: CC BY 3.0 IGO."

- Yartey, C. A., \& Adjasi, C. K. (2007). Stock market development in Sub-Saharan Africa: Critical issues and challenges. 


\section{APPENDIX}

\section{The ADF test for all the ARDL model variables:}

\section{Table 8 ADF test results for the Real GDP Growth Rate (Dependent Variable)}

Augmented Dickey-Fuller Unit Root Test on GRGDP

\begin{tabular}{|c|c|c|c|c|}
\hline \multicolumn{5}{|c|}{$\begin{array}{l}\text { Null Hypothesis: GRGDP has a unit root } \\
\text { Exogenous: Constant } \\
\text { Lag Length: } 3 \text { (Automatic - based on AIC, maxlag=4) }\end{array}$} \\
\hline & & & t-Statistic & Prob.* \\
\hline \multicolumn{3}{|c|}{ Augmented Dickey-Fuller test statistic } & -3.586477 & 0.0106 \\
\hline Test critical values: & $\begin{array}{l}1 \% \text { level } \\
5 \% \text { level } \\
10 \% \text { level }\end{array}$ & & $\begin{array}{l}-3.610453 \\
-2.938987 \\
-2.607932\end{array}$ & \\
\hline \multicolumn{5}{|c|}{ *MacKinnon (1996) one-sided p-values. } \\
\hline \multicolumn{5}{|c|}{$\begin{array}{l}\text { Augmented Dickey-Fuller Test Equation } \\
\text { Dependent Variable: D(GRGDP) } \\
\text { Method: Least Squares } \\
\text { Date: 06/05/21 Time: } 16: 30 \\
\text { Sample (adjusted): } 2010 \mathrm{Q} 2 \text { 2019Q4 } \\
\text { Included observations: } 39 \text { after adjustments }\end{array}$} \\
\hline Variable & Coefficient & Std. Error & t-Statistic & Prob. \\
\hline GRGDP(-1) & -1.912919 & 0.533370 & -3.586477 & 0.0010 \\
\hline $\mathrm{D}(\mathrm{GRGDP}(-1))$ & 0.423518 & 0.404174 & 1.0478 & 0.3021 \\
\hline $\mathrm{D}(\mathrm{GRGDP}(-2))$ & 0.048658 & 0.271159 & 0.179446 & 0.8587 \\
\hline D(GRGDP(-3)) & -0.346416 & 0.146227 & -2.369 & 0.0237 \\
\hline c & & 0.593891 & 3.080636 & \\
\hline R-squared & 0.892759 & \multirow{7}{*}{\multicolumn{2}{|c|}{$\begin{array}{l}\text { Mean dependent var } \\
\text { S.D. dependent var } \\
\text { Akaike info criterion } \\
\text { Schwarz criterion } \\
\text { Hannan-Quinn criter. } \\
\text { Durbin-Watson stat }\end{array}$}} & -0.127894 \\
\hline Adjusted R-squared & 0.880142 & & & 5.012892 \\
\hline S.E. of regression & 1.735490 & & & 4.059666 \\
\hline Sum squared resid & 102.4054 & & & 4.272943 \\
\hline Log likelihood & -74.16348 & & & 4.136188 \\
\hline F-statistic & 70.76039 & & & 2.102896 \\
\hline & & & & \\
\hline
\end{tabular}

\section{Table 10 ADF test results for the Market}

\section{Capitalization}

Augmented Dickey-Fuller Unit Root Test on D(MCAP)

\begin{tabular}{|c|c|c|c|c|}
\hline \multicolumn{5}{|c|}{$\begin{array}{l}\text { Null Hypothesis: } \mathrm{D}(\mathrm{MCAP}) \text { has a unit root } \\
\text { Exogenous: Constant } \\
\text { Lag Length: } 0 \text { (Automatic - based on AIC, maxlag=4) }\end{array}$} \\
\hline & & & t-Statistic & Prob.* \\
\hline \multicolumn{3}{|c|}{ Augmented Dickey-Fuller test statistic } & -6.292906 & 0.0000 \\
\hline Test critical values: & $\begin{array}{l}1 \% \text { level } \\
5 \% \text { level } \\
10 \% \text { level }\end{array}$ & & $\begin{array}{l}-3.596616 \\
-2.933158 \\
-2.604867\end{array}$ & \\
\hline \multicolumn{5}{|c|}{ "MacKinnon (1996) one-sided p-values. } \\
\hline \multicolumn{5}{|c|}{$\begin{array}{l}\text { Augmented Dickey-Fuller Test Equation } \\
\text { Dependent Variable: D(MCAP,2) } \\
\text { Method: Least Squares } \\
\text { Date: } 06 / 05 / 21 \text { Time: } 16: 00 \\
\text { Sample (adjusted): } 2009 \mathrm{Q} 32019 \mathrm{Q} 4 \\
\text { Included observations: } 42 \text { after adjustments }\end{array}$} \\
\hline Variable & Coefficient & Std. Error & t-Statistic & Prob. \\
\hline$\underset{C}{\mathrm{D}(\mathrm{MCAP}(-1))}$ & $\begin{array}{r}-0.977786 \\
0.054016\end{array}$ & $\begin{array}{l}0.155379 \\
1.415857\end{array}$ & $\begin{array}{r}-6.292906 \\
0.038150\end{array}$ & $\begin{array}{l}0.0000 \\
0.9698\end{array}$ \\
\hline $\begin{array}{l}\text { R-squared } \\
\text { Adjusted R-squared } \\
\text { S.E. of regression } \\
\text { Sum squared resid } \\
\text { Log likelihood } \\
\text { F-statistic } \\
\text { Prob(F-statistic) }\end{array}$ & $\begin{array}{r}0.497492 \\
0.484929 \\
9.166813 \\
3361.218 \\
-151.6256 \\
39.60067 \\
0.000000\end{array}$ & \multicolumn{2}{|c|}{$\begin{array}{l}\text { Mean dependent var } \\
\text { S.D. dependent var } \\
\text { Akaike info criterion } \\
\text { Schwarz criterion } \\
\text { Hannaan-Quinn criter. } \\
\text { Durbin-Watson stat }\end{array}$} & $\begin{array}{r}-0.340302 \\
12.77276 \\
7.315504 \\
7.398250 \\
7.345834 \\
2.020048\end{array}$ \\
\hline
\end{tabular}

Table 9 ADF test results for the Primary Education

Augmented Dickey-Fuller Unit Root Test on $\mathrm{D}(\mathrm{PI})$

\begin{tabular}{|c|c|c|c|c|}
\hline \multicolumn{5}{|c|}{$\begin{array}{l}\text { Null Hypothesis: } \mathrm{D}(\mathrm{PI}) \text { has a unit root } \\
\text { Exogenous: Constant } \\
\text { Lag Length: } 3 \text { (Automatic - based on AIC, maxlag=4) }\end{array}$} \\
\hline \multicolumn{5}{|c|}{ t-Statistic } \\
\hline \multicolumn{3}{|c|}{ Augmented Dickey-Fuller test statistic } & -5.378035 & 0.0001 \\
\hline Test critical values: & $\begin{array}{l}1 \% \text { level } \\
5 \% \text { level } \\
10 \% \text { level }\end{array}$ & & $\begin{array}{l}-3.610453 \\
-2.938987 \\
-2.607932\end{array}$ & \\
\hline \multicolumn{5}{|c|}{ "MacKinnon (1996) one-sided p-values. } \\
\hline \multirow{4}{*}{\multicolumn{5}{|c|}{$\begin{array}{l}\text { Augmented Dickey-Fuller Test Equation } \\
\text { Dependent Variable: D(PI,2) } \\
\text { Method: Least Squares } \\
\text { Date: } 06 / 05 / 21 \text { Time: } 15: 54 \\
\text { Sample (adjusted): } 2010 \mathrm{Q} 2 \text { 2019Q4 } \\
\text { Included observations: } 39 \text { after adjustments }\end{array}$}} \\
\hline & & & & \\
\hline & & & & \\
\hline & & & & \\
\hline Variable & Coefficient & Std. Error & t-Statistic & Prob. \\
\hline $\mathrm{D}(\mathrm{PI}(-1))$ & -1.033224 & 0.192119 & -5.378035 & 0.0000 \\
\hline $\mathrm{D}(\mathrm{PI}(-1), 2)$ & 0.355456 & 0.173021 & 2.054411 & 0.0477 \\
\hline $\mathrm{D}(\mathrm{PI}(-2), 2)$ & 0.490187 & 0.159215 & 3.078779 & 0.0041 \\
\hline $\mathrm{D}(\mathrm{PI}(-3), 2)$ & 0.547617 & 0.140470 & 3.898460 & 0.0004 \\
\hline $\mathrm{C}$ & 0.129024 & 0.104062 & 1.239878 & 0.2235 \\
\hline & & \multirow{6}{*}{\multicolumn{2}{|c|}{$\begin{array}{l}\text { Mean dependent var } \\
\text { S.D. dependent var } \\
\text { Akaike info criterion } \\
\text { Schwarz criterion } \\
\text { Hannan-Quinn criter. } \\
\text { Durbin-Watson stat }\end{array}$}} & -0.005117 \\
\hline Adjusted R-squared & 0.468139 & & & 0.864493 \\
\hline S.E. of regression & 0.630465 & & & $\begin{array}{l}2.034490 \\
2.247767\end{array}$ \\
\hline Sum squared resid & 13.51452 & & & 2.247767 \\
\hline Log likelihood & -34.67256 & & & 2.111012 \\
\hline F-statistic & 9.361800 & & & 1.852983 \\
\hline Prob(F-statistic) & 0.000033 & \multicolumn{2}{|c|}{ Durbin-Watson stat } & \\
\hline
\end{tabular}

Table 11 ADF test results for the M2.

Augmented Dlckey-Fuller Unlt Root Test on D(M2)

\begin{tabular}{|c|c|c|c|c|}
\hline \multicolumn{5}{|c|}{$\begin{array}{l}\text { Null HypothesIs: D(M2) has a unlt root } \\
\text { Exogenous: Constant } \\
\text { Lag Length: } 0 \text { (Automatlc - based on AIC, maxlag=4) }\end{array}$} \\
\hline & & & t-Statistic & Prob.* \\
\hline \multicolumn{3}{|c|}{ Augmented Dickey-Fuller test statistlc } & -7.376696 & 0.0000 \\
\hline \multicolumn{3}{|c|}{$\begin{array}{ll}\text { Test critical values: } & 1 \% \text { level } \\
& 5 \% \text { level } \\
& 10 \% \text { level }\end{array}$} & $\begin{array}{l}-3.596616 \\
-2.933158 \\
-2.604867\end{array}$ & \\
\hline \multicolumn{5}{|c|}{ "MacKInnon (1996) one-slded p-values. } \\
\hline \multicolumn{5}{|c|}{$\begin{array}{l}\text { Augmented Dickey-Fuller Test Equation } \\
\text { Dependent Varlable: D(M2,2) } \\
\text { Method: Least Squares } \\
\text { Date: } 06 / 05 / 21 \text { Tlme: } 16: 40 \\
\text { Sample (adjusted): } 2009 \mathrm{Q} 32019 \mathrm{Q} 4 \\
\text { Included observations: } 42 \text { after adjustments }\end{array}$} \\
\hline Varlable & Coefficlent & Std. Error & t-Statlstlc & Prob. \\
\hline $\begin{array}{c}\mathrm{D}(\mathrm{M} 2(-1)) \\
\mathrm{C}\end{array}$ & $\begin{array}{r}-1.155214 \\
7.935585\end{array}$ & $\begin{array}{l}0.156603 \\
3.118941\end{array}$ & $\begin{array}{r}-7.376696 \\
2.544320\end{array}$ & $\begin{array}{l}0.0000 \\
0.0149\end{array}$ \\
\hline $\begin{array}{l}\text { R-squared } \\
\text { Adjusted R-squared } \\
\text { S.E. of regresslon } \\
\text { Sum squared resid } \\
\text { Log llkellhood } \\
\text { F-statlstlc } \\
\text { Prob(F-statlstic) }\end{array}$ & $\begin{array}{r}0.576341 \\
0.565750 \\
18.91323 \\
14308.40 \\
-182.0450 \\
54.41565 \\
0.000000\end{array}$ & \multicolumn{2}{|c|}{$\begin{array}{l}\text { Mean dependent var } \\
\text { S.D. dependent var } \\
\text { Akalke Info crtterlon } \\
\text { Schwarz criterlon } \\
\text { Hannan-Qulnn criter. } \\
\text { Durbln-Watson stat }\end{array}$} & $\begin{array}{r}-0.181759 \\
28.70091 \\
8.764048 \\
8.846794 \\
8.794378 \\
2.045358\end{array}$ \\
\hline
\end{tabular}


Table 12 ADF test results for the Trade Openness.

Augmented Dickey-Fuller Unit Root Test on D(TRD_OP)

\begin{tabular}{|c|c|c|c|c|}
\hline \multicolumn{5}{|c|}{$\begin{array}{l}\text { Null Hypothesis: D(TRD_OP) has a unit root } \\
\text { Exogenous: None } \\
\text { Lag Length: } 4 \text { (Automatic - based on AIC, maxlag=4) }\end{array}$} \\
\hline & & & t-Statistic & Prob.* \\
\hline \multicolumn{3}{|c|}{ Augmented Dickey-Fuller test statistic } & -2.101369 & 0.0357 \\
\hline Test critical values: & $\begin{array}{l}1 \% \text { level } \\
5 \% \text { level } \\
10 \% \text { level }\end{array}$ & & $\begin{array}{l}-2.627238 \\
-1.949856 \\
-1.611469\end{array}$ & \\
\hline \multicolumn{5}{|c|}{ "MacKinnon (1996) one-sided p-values. } \\
\hline \multicolumn{5}{|c|}{$\begin{array}{l}\text { Augmented Dickey-Fuller Test Equation } \\
\text { Dependent Variable: D(TRD_OP,2) } \\
\text { Method: Least Squares } \\
\text { Date: } 06 / 05 / 21 \text { Time: } 16: 44 \\
\text { Sample (adjusted): } 2010 Q 32019 Q 4 \\
\text { Included observations: } 38 \text { after adjustments }\end{array}$} \\
\hline Variable & Coefficient & Std. Error & t-Statistic & Prob. \\
\hline D(TRD_OP(-1)) & -0.363537 & 0.173000 & -2.101369 & 0.0433 \\
\hline D(TRD_OP(-1),2) & 0.042787 & 0.165179 & 0.259034 & 0.7972 \\
\hline D(TRD_OP(-2),2) & 0.205765 & 0.161837 & 1.271430 & 0.2125 \\
\hline D(TRD_OP(-3),2) & 0.250198 & 0.161518 & 1.549041 & 0.1309 \\
\hline D(TRD_OP(-4),2) & -0.376187 & 0.157745 & -2.384784 & 0.0230 \\
\hline R-squared & 0.442599 & \multirow{6}{*}{\multicolumn{2}{|c|}{$\begin{array}{l}\text { Mean dependent var } \\
\text { S.D. dependent var } \\
\text { Akaike info criterion } \\
\text { Schwarz criterion } \\
\text { Hannan-Quinn criter. }\end{array}$}} & -0.026339 \\
\hline Adjusted R-squared & 0.375035 & & & 1.832198 \\
\hline S.E. of regression & 1.448439 & & & 3.700929 \\
\hline Sum squared resid & 69.23315 & & & 3.916400 \\
\hline Log likelihood & -65.31764 & & & 3.777592 \\
\hline Durbin-Watson stat & 1.977482 & & & \\
\hline
\end{tabular}

Table 13 ADF test results for the stock Turnover ratio.

Augmented Dickey-Fuller Unit Root Test on D(TR)

\begin{tabular}{|c|c|c|c|c|}
\hline \multicolumn{5}{|c|}{$\begin{array}{l}\text { Null Hypothesis: } D(T R) \text { has a unit root } \\
\text { Exogenous: Constant } \\
\text { Lag Length: } 0 \text { (Automatic - based on AIC, maxlag=4) }\end{array}$} \\
\hline & & & t-Statistic & Prob. ${ }^{*}$ \\
\hline \multicolumn{3}{|c|}{ Augmented Dickey-Fuller test statistic } & -5.529848 & 0.0000 \\
\hline Test critical values: & $\begin{array}{l}1 \% \text { level } \\
5 \% \text { level } \\
10 \% \text { level }\end{array}$ & & $\begin{array}{l}-3.596616 \\
-2.933158 \\
-2.604867\end{array}$ & \\
\hline \multicolumn{5}{|c|}{ "MacKinnon (1996) one-sided p-values. } \\
\hline \multicolumn{5}{|c|}{$\begin{array}{l}\text { Augmented Dickey-Fuller Test Equation } \\
\text { Dependent Variable: D(TR,2) } \\
\text { Method: Least Squares } \\
\text { Date: 06/05/21 Time: } 16: 46 \\
\text { Sample (adjusted): } 2009 \mathrm{2} 2019 \mathrm{Q} 4 \\
\text { Included observations: } 42 \text { after adjustments }\end{array}$} \\
\hline Variable & Coefficient & Std. Error & t-Statistic & Prob. \\
\hline $\begin{array}{c}\mathrm{D}(\operatorname{TR}(-1)) \\
\mathrm{C}\end{array}$ & $\begin{array}{r}-0.861050 \\
0.122063\end{array}$ & $\begin{array}{l}0.155710 \\
0.208962\end{array}$ & $\begin{array}{r}-5.529848 \\
0.584138\end{array}$ & $\begin{array}{l}0.0000 \\
0.5624\end{array}$ \\
\hline $\begin{array}{l}\text { R-squared } \\
\text { Adjusted R-squared } \\
\text { S.E. of regression } \\
\text { Sum squared resid } \\
\text { Log likelihood } \\
\text { F-statistic } \\
\text { Prob(F-statistic) }\end{array}$ & $\begin{array}{r}0.433261 \\
0.419092 \\
1.349800 \\
72.87837 \\
-71.16899 \\
30.57922 \\
0.000002\end{array}$ & \multicolumn{2}{|c|}{$\begin{array}{l}\text { Mean dependent var } \\
\text { S.D. dependent var } \\
\text { Akaike info criterion } \\
\text { Schwarz criterion } \\
\text { Hannan-Quinn criter. } \\
\text { Durbin-Watson stat }\end{array}$} & $\begin{array}{l}0.028670 \\
1.770989 \\
3.484237 \\
3.566984 \\
3.514567 \\
1.996329\end{array}$ \\
\hline
\end{tabular}


Estimation Results:

Table 14 ARDL model results

\begin{tabular}{|c|c|c|c|c|}
\hline \multicolumn{5}{|c|}{$\begin{array}{l}\text { Dependent Variable: GRGDP } \\
\text { Method: ARDL } \\
\text { Date: 06/04/21 Time: } 18: 47 \\
\text { Sample (adjusted): } 2010 Q 1201904 \\
\text { Included observations: } 40 \text { after adjustments } \\
\text { Maximum dependent lags: } 4 \text { (Automatic selection) } \\
\text { Model selection method: Akaike info criterion (AIC) } \\
\text { Dynamic regressors (4 lags, automatic): PI TRD OP MCAP TR M2 } \\
\text { Fixed regressors: C } \\
\text { Number of models evalulated: } 12500 \\
\text { Selected Model: ARDL(3, } 1,3,3,4,4 \text { ) } \\
\text { Note: final equation sample is larger than selection sample }\end{array}$} \\
\hline Variable & Coefficient & Std. Error & 1-Statistic & Prob. \\
\hline GRGDP(-1) & -1.053660 & 0.108644 & -9.698243 & 0.0000 \\
\hline GRGDP(-2) & -0.923166 & 0.103056 & -8.957939 & 0.0000 \\
\hline $\operatorname{GRGDP}(-3)$ & -0.949264 & 0.095535 & -9.936259 & 0.0000 \\
\hline $\mathrm{PI}$ & 2.206282 & 0.344778 & 6.399132 & 0.0000 \\
\hline $\mathrm{PI}(-1)$ & -1.413280 & 0.312344 & -4.524749 & 0.0003 \\
\hline TRD OP & 0.043086 & 0.228607 & 0.188470 & 0.8529 \\
\hline TRD OP(-1) & -0.176792 & 0.363992 & -0.485702 & 0.6338 \\
\hline TRD OP(-2) & -0.471461 & 0.387510 & -1.216641 & 0.2414 \\
\hline TRD_OP(-3) & 0.317618 & 0.248466 & 1.278315 & 0.2194 \\
\hline MCAP & 0.128464 & 0.106236 & 1.209233 & 0.2441 \\
\hline $\operatorname{MCAP}(-1)$ & -0.151786 & 0.117712 & -1.289473 & 0.2156 \\
\hline MCAP(-2) & -0.033782 & 0.087858 & -0.384508 & 0.7057 \\
\hline $\operatorname{MCAP}(-3)$ & 0.061631 & 0.080808 & 0.762679 & 0.4568 \\
\hline TR & 0.212933 & 0.572414 & 0.371992 & 0.7148 \\
\hline $\operatorname{TR}(-1)$ & -1.054633 & 0.779088 & -1.353677 & 0.1947 \\
\hline $\operatorname{TR}(-2)$ & -0.528081 & 0.670059 & -0.788111 & 0.4422 \\
\hline $\operatorname{TR}(-3)$ & 0.243590 & 0.663896 & 0.366911 & 0.7185 \\
\hline $\operatorname{TR}(-4)$ & -0.330296 & 0.276873 & -1.192951 & 0.2503 \\
\hline M2 & 0.009039 & 0.016793 & 0.538238 & 0.5978 \\
\hline M2(-1) & -0.000733 & 0.020626 & -0.035558 & 0.9721 \\
\hline M2(-2) & 0.036018 & 0.018264 & 1.972050 & 0.0661 \\
\hline M2(-3) & 0.009534 & 0.021833 & 0.436663 & 0.6682 \\
\hline M2(-4) & -0.048121 & 0.017021 & .2 .827138 & 0.0121 \\
\hline C & .55 .02691 & 17.76151 & -3.098098 & 0.0069 \\
\hline & & Mean deper & dent var & 1.014076 \\
\hline Adjusted R-squared & 0.863549 & S.D. depend & lent var & 3.102983 \\
\hline S.E. of regression & 1.146219 & Akaike info & griterion & 3.394524 \\
\hline Sum squared resid & 21.02108 & Schwarz crit & erion & 4.407851 \\
\hline Log likelihood & -43.89047 & Hannan-Qu & nn criter. & 3.760911 \\
\hline F-statistic & 11.73118 & Durbin-Wat: & on stat & 2.198517 \\
\hline Prob(F-statistic) & 0.000003 & & & \\
\hline
\end{tabular}

\section{Table 15 Bounds test, short-run and long-run coefficients estimates}

\begin{tabular}{|c|c|c|c|c|}
\hline \multicolumn{5}{|c|}{ 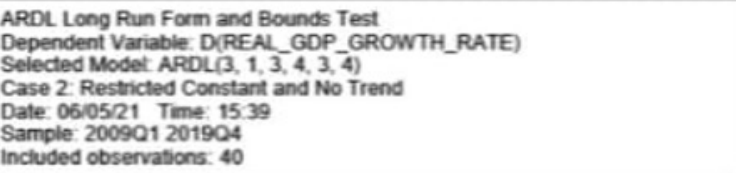 } \\
\hline \multicolumn{5}{|c|}{ Conditonal Error Correction Regression } \\
\hline Variable & Coefficient & Sta Error & 1-Statistic & Prob. \\
\hline c & -55.02691 & 17.76151 & -3.098098 & 0.0069 \\
\hline REAL_GDP_GROWTH_ & -3926090 & 0.258897 & -15.16467 & 00000 \\
\hline PRIMARYYEDUCATION & 0.793002 & 0.217821 & 3.640620 & 00022 \\
\hline MCAP(-1) & 0.004527 & 0.069607 & 0.050516 & 0.9603 \\
\hline$M R$ GDP(-1) & 0.005735 & 0.011619 & 0.493604 & 0.6283 \\
\hline TRADE_ OF_GDP_t & -0.287549 & 0.087959 & -3.269111 & 00048 \\
\hline TURNOVER RATIO O & -1.456486 & 0.603879 & -2411883 & 0.0282 \\
\hline DCREAL GDP GROWT & 1872430 & 0.173713 & 10.77889 & 0,0000 \\
\hline D(REAL_GDP_GROWT & 0.949264 & 0.095535 & 9.936259 & 00000 \\
\hline DPPRIMĀRY_ËDUCATI & 2206282 & 0.344778 & 6.399132 & 00000 \\
\hline DOMCAP & 0.128464 & 0.106236 & 1.209233 & 02441 \\
\hline DOMCAP(-1)) & -0.027849 & 0.087673 & -0.317644 & 0.7549 \\
\hline DOACAP(-2)1) & -0.061631 & 0.080808 & -0.762679 & 0.4568 \\
\hline DONOGDP) & 0.009039 & 0.016793 & 0.538238 & 0.5978 \\
\hline DON__GOP(-1)) & 0.002570 & 0.014614 & 0.175859 & 08626 \\
\hline DQME_GDP(-2) & 0.038588 & 0.014961 & 2579204 & 00202 \\
\hline DQN_GDP(-3)) & 0.048121 & 0.017021 & 2827138 & 00121 \\
\hline D(TRADE OF_GDPJ & 0.043086 & 0.228607 & 0.188470 & 0.8529 \\
\hline OF GDP & 0.153843 & 0.235263 & 0.653919 & 05225 \\
\hline DTTRADE OF-GDP- & -0.317618 & 0.248466 & -1278315 & 0.2194 \\
\hline DTTUPEOVER_RATIO_- & 0.212933 & 0.572414 & 0.371992 & 07148 \\
\hline DCTUREVOVER_RATIO_- & 0.614786 & 0692005 & 0.888413 & 0.3875 \\
\hline DCTURAVIOVER RATIO- & 0.086705 & 0.703269 & 0.123289 & 09034 \\
\hline DCTURAVIER RATIO- & 0.330296 & 0.276873 & 1.192951 & 0.2503 \\
\hline \multicolumn{5}{|c|}{ "D-value incompatile with 1-Bounds distribution. } \\
\hline \multicolumn{5}{|c|}{$\begin{array}{l}\text { Levets Equation } \\
\text { Case 2: Restricted Constant and No Trend }\end{array}$} \\
\hline Variable & Coefficient & Ste. Error & F Statistic & Prob. \\
\hline PRIMARY_EDUCATION & 0.201983 & 0.054932 & 3.676982 & 0,0020 \\
\hline MCAP & 0.001153 & 0,022808 & 0.050550 & 09603 \\
\hline M2_GDP & 0.001461 & 0.002973 & 0.491306 & 06299 \\
\hline TRADE OF_GDP & -0073241 & 0.023095 & -3.171322 & 00059 \\
\hline TURNOVER_RATIO_OO & -0.370976 & 0.157484 & -2355640 & 00316 \\
\hline c & -14.01570 & 4.362275 & -3.212934 & 0.0054 \\
\hline \multicolumn{5}{|c|}{ 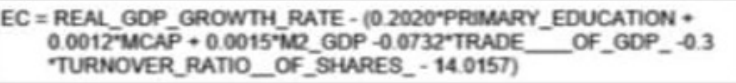 } \\
\hline F-Bounds Test & \multicolumn{4}{|c|}{ Null Hypothesis: No levels retationship } \\
\hline Test Statistic & Value & Signit. & $y(0)$ & (1) \\
\hline \multirow[b]{2}{*}{$\begin{array}{l}\text { F-statistic } \\
\mathrm{K}\end{array}$} & & \multicolumn{3}{|c|}{ Asymptotic: $n=1000$} \\
\hline & $\begin{array}{l}38.23185 \\
5\end{array}$ & $\begin{aligned} 10 \% \\
5 \%\end{aligned}$ & $\begin{array}{l}208 \\
239\end{array}$ & $333^{3}$ \\
\hline \multirow{6}{*}{ Actual Sample Size } & & $25 \%$ & 27 & 3.73 \\
\hline & & $1 \%$ & 3.06 & 4.15 \\
\hline & 40 & \multicolumn{3}{|c|}{ Finite Sample: $n=40$} \\
\hline & & $10 \%$ & 2306 & 3.353 \\
\hline & & $5 \%$ & 2734 & 392 \\
\hline & & $1 \%$ & 3.657 & 5.256 \\
\hline
\end{tabular}




\section{Stability and Heteroskedasticity tests}

\section{Table 16 Ramsey RESET test results}

\begin{tabular}{|c|c|c|c|c|}
\hline \multicolumn{5}{|c|}{ 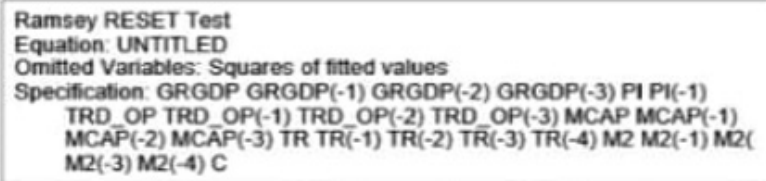 } \\
\hline $\begin{array}{l}\text { 1-statistic } \\
\text { F-statistic } \\
\text { Liketihood ratio }\end{array}$ & $\begin{array}{l}\text { Value } \\
0.128140 \\
0.016420 \\
0.043762\end{array}$ & $\begin{array}{c}\text { df } \\
(1,15) \\
1\end{array}$ & $\begin{array}{c}\text { Probability } \\
0.8997 \\
0.8997 \\
0.8343\end{array}$ & \\
\hline $\begin{array}{l}\text { Test SSR } \\
\text { Restricted SSR } \\
\text { Unrestricted SSR }\end{array}$ & $\begin{array}{l}\text { Sum of Sq } \\
0.022986 \\
21.02108 \\
20.99810\end{array}$ & $\begin{array}{c}\text { of } \\
1 \\
16 \\
15\end{array}$ & $\begin{array}{c}\text { Mean Square } \\
0.022986 \\
1.313818 \\
1.399873\end{array}$ & \\
\hline $\begin{array}{l}\text { Restricted LogL } \\
\text { Unrestricted LogL. }\end{array}$ & $\begin{array}{c}\text { Value } \\
-43.89047 \\
-43.86859\end{array}$ & & & \\
\hline \multicolumn{5}{|c|}{$\begin{array}{l}\text { Unrestricted Test Equation: } \\
\text { Dependent Variable: GRGDP } \\
\text { Mothod: Least Squares } \\
\text { Date: 06/05/21 Time: } 17: 17 \\
\text { Sample: } 201001 \text { 201904 } \\
\text { Included observations: } 40\end{array}$} \\
\hline Variable & Coefficient & Std. Error & 1-Statistic & Prob. \\
\hline $\begin{array}{c}\text { GRGDP(-1) } \\
\text { GRGDP(-2) } \\
\text { GRGDP(-3) } \\
\text { PI } \\
\text { PI(-1) } \\
\text { TRD_OP } \\
\text { TRD_OP(-1) } \\
\text { TRD_OP(-2) } \\
\text { TRD_OP(-3) } \\
\text { MCAP } \\
\text { MCAP(-1) } \\
\text { MCAP(-2) } \\
\text { MCAP(-3) } \\
\text { TR } \\
\text { TR(-1) } \\
\text { TR(-2) } \\
\text { TR(-3) } \\
\text { TR(-4) } \\
\text { M2 } \\
\text { ME(-1) } \\
\text { M2(-2) } \\
\text { MZ(-3) } \\
\text { ME(-4) } \\
\text { C } \\
\text { FITED } 2\end{array}$ & $\begin{array}{r}-1.055537 \\
-0.923402 \\
-0.946091 \\
2.215175 \\
-1.425810 \\
0.042034 \\
-0.178795 \\
-0.468457 \\
0.319550 \\
0.126022 \\
-0.150965 \\
-0.030882 \\
0.059875 \\
0.200748 \\
-1.051258 \\
-0.516500 \\
0.233111 \\
-0.320567 \\
0.009019 \\
-0.000456 \\
0.035932 \\
0.009427 \\
-0.048167 \\
-54.67986 \\
-0.004446\end{array}$ & $\begin{array}{l}0.113098 \\
0.106393 \\
0.101676 \\
0.362594 \\
0.336913 \\
0.236118 \\
0.376049 \\
0.400686 \\
0.256917 \\
0.111304 \\
0.121675 \\
0.093471 \\
0.034532 \\
0.598466 \\
0.804630 \\
0.697534 \\
0.690156 \\
0.295710 \\
0.017335 \\
0.021401 \\
0.018864 \\
0.022552 \\
0.017573 \\
18.53295 \\
0.034693\end{array}$ & $\begin{array}{r}-9.332905 \\
-8.679151 \\
-9.304912 \\
6.109245 \\
-4.231983 \\
0.178022 \\
-0.475456 \\
-1.169138 \\
1.243785 \\
1.132230 \\
-1.240732 \\
-0.330387 \\
0.708310 \\
0.335437 \\
-1.306512 \\
-0.740466 \\
0.337765 \\
-1.084060 \\
0.520263 \\
-0.021297 \\
1.904744 \\
0.418042 \\
-2.740920 \\
-2.950413 \\
-0.128140\end{array}$ & $\begin{array}{l}0.0000 \\
0.0000 \\
0.0000 \\
0.0000 \\
0.0007 \\
0.8611 \\
0.6413 \\
0.2606 \\
0.2327 \\
0.2753 \\
0.2339 \\
0.7457 \\
0.4896 \\
0.7419 \\
0.2111 \\
0.4705 \\
0.7402 \\
0.2955 \\
0.6105 \\
0.9833 \\
0.0762 \\
0.6818 \\
0.0152 \\
0.0099 \\
0.8997\end{array}$ \\
\hline $\begin{array}{l}\text { R-squared } \\
\text { Adjusted R-squared } \\
\text { S.E. of regression } \\
\text { Sum squared resid }\end{array}$ & $\begin{array}{l}0.944081 \\
0.854612 \\
1.183162 \\
20.99810\end{array}$ & $\begin{array}{l}\text { S.D. depen } \\
\text { Akaike into } \\
\text { Schwarz cn }\end{array}$ & $\begin{array}{l}\text { andent var } \\
\text { ndent var } \\
\text { criterion } \\
\text { niterion }\end{array}$ & $\begin{array}{l}1.014076 \\
3.102983 \\
3.443429 \\
4.498979\end{array}$ \\
\hline
\end{tabular}

\section{Table 17 Breusch-Pagan-Godfrey Heteroskedasticity test results}

\begin{tabular}{|c|c|c|c|c|}
\hline \multicolumn{5}{|c|}{$\begin{array}{l}\text { Heteroskedasticily Test Breusch-Pagan-Godtrey } \\
\text { Null hypothesis Homoskedasticity }\end{array}$} \\
\hline \multirow{3}{*}{$\begin{array}{l}\text { F-statistic } \\
\text { Obs'R-squared } \\
\text { Scaled explained SS }\end{array}$} & 1.652429 & \multicolumn{2}{|c|}{ Prob $F(23,16)$} & 0.1519 \\
\hline & 28.14944 & Prob Chis & vare (23) & 0.2102 \\
\hline & 4702839 & Prob Chis & vare(23) & 1.0000 \\
\hline \multicolumn{5}{|c|}{ Test Equation: } \\
\hline \multirow{2}{*}{\multicolumn{5}{|c|}{$\begin{array}{l}\text { Dependent Variable: RESID*2 } \\
\text { Method Least Squares }\end{array}$}} \\
\hline & & & & \\
\hline \multicolumn{5}{|c|}{ Date: 06/05/21 Time: 1722} \\
\hline \multirow{2}{*}{\multicolumn{5}{|c|}{$\begin{array}{l}\text { Sample } 201001201904 \\
\text { Included observations: } 40\end{array}$}} \\
\hline & & & & \\
\hline Variable & Coefficient & Std Error & 1-Statistic & Prob. \\
\hline C & -11.76146 & 10.12785 & -1.161299 & 0.2626 \\
\hline GRGDP(-1) & -0.007295 & 0.061950 & -0.117750 & 0.9077 \\
\hline GRGDP(-2) & -0073446 & 0058764 & -1249862 & 02293 \\
\hline GRGDP(-3) & 0.013796 & 0.054476 & 0.253293 & 0.8033 \\
\hline $\mathrm{PI}$ & -0085419 & 0.196597 & -0434489 & 06697 \\
\hline$P Y(-1)$ & 0.266861 & 0.178103 & 1.498353 & 0.1535 \\
\hline TRD_OP & 0.104515 & 0.130355 & 0.801770 & 0.4344 \\
\hline TRD OP(-1) & 0.052165 & 0.207553 & 0.251334 & 0.8048 \\
\hline TRDOP(-2) & .0211590 & 0.220964 & -0.957579 & 0.3525 \\
\hline TRD OP $(-3)$ & 0.070585 & 0.141679 & 0498205 & 06251 \\
\hline MCAP & -0.045379 & 0.060577 & -0.749109 & 0.4647 \\
\hline $\operatorname{MCAP}(-1)$ & 0.057740 & 0067121 & 0860243 & 0.4024 \\
\hline $\operatorname{MCAP}(-2)$ & 0.029063 & 0050098 & 0.580121 & 05699 \\
\hline MCAP (-3) & -0.104554 & 0046078 & -2269076 & 00375 \\
\hline TR & -0270061 & 0326398 & .0827399 & 0.4202 \\
\hline $\operatorname{TR}(-1)$ & 0.340120 & 0.444246 & 0.765612 & 0.4551 \\
\hline $\operatorname{TR}(-2)$ & 0.379042 & 0382076 & 0.992057 & 0.3359 \\
\hline $\operatorname{TR}(-3)$ & -0.872962 & 0.378562 & -2305994 & 0.0348 \\
\hline $\operatorname{TR}(-4)$ & -0035841 & 0.157877 & .0227020 & 08233 \\
\hline MQ & -0.002373 & 0.009576 & -0.247851 & 0.8074 \\
\hline$M(-1)$ & 0012557 & 0011761 & 1067710 & 03015 \\
\hline$M(-2)$ & -0.008993 & 0.010414 & -0.863548 & 0.4006 \\
\hline$M 2(-3)$ & 0.015849 & 0.012449 & 1.273120 & 0.2212 \\
\hline$M 2(-4)$ & -0.011910 & 0.009706 & -1.227137 & 0.2375 \\
\hline R-squared & 0.703736 & Mean deper & dent var & 0.525527 \\
\hline Adusted R-squared & 0.277856 & SD. depenc & ent var & 0.769118 \\
\hline $\mathrm{SE}$ of regression & 0653589 & Akake into & riterion & 2271034 \\
\hline Sum squared resid & 6.834861 & Schwarz chil & erion & 3284361 \\
\hline Log Bkelihood & -21.42067 & Hannan-Ou & nn criter. & 2637421 \\
\hline F-statisfic & 1652429 & Durbin-Wat: & on stat & 1.756930 \\
\hline Prob(F-statisfic) & 0.151927 & & & \\
\hline
\end{tabular}

